\title{
THREATS AND CONSERVATION PROBLEMS OF NON-HUMAN PRIMATES IN MOIST DECIDUOUS FOREST OF BANGLADESH
}

\author{
HABIBON NAHER $^{1}$, SHAWKAT IMAM KHAN ${ }^{2}$ AND TANVIR AHMED $^{1}$ \\ ${ }^{1}$ Department of Zoology, Jagannath Unversity, Dhaka, Bngladesh \\ ${ }^{2}$ Department of Natural History, Bangladesh National Museum, Shahbag, Dhaka, Bangladesh
}

\begin{abstract}
A study was conducted at the Madhupur deciduous forest, Tangail from April 2015 to October 2015. It was carried out. Formal and informal questionnaire survey was used to interview the forest staffs and local people of the peripheral villages of Madhupur forest. Habitat destruction due to expansion of agricultural land and illegal logging and firewood collection was the prime threats of primates' conservation especially Langur endurance. Hunting by ethnic people for using food was another threat for primates' survival. Diseases and road accident were additional cause of threats. Crop raid was the main factor for human primates' conflict. Paddy, pineapple and jackfruits were severely damaged by primates as they spoiled more crops than they actually eat. Time and economic loss was due to engagement of people guarding the crop field till harvesting.
\end{abstract}

Key words: Capped langur, Rhesus macaque, Habitat destruction

\section{Introduction}

The non-human primates are represented with 63 genera and about 600 species and subspecies in some 92 countries (Chopra et al. 2013). Among these 25 species are recorded from the Indian sub-continent (op. cit.) and 10 species occur in Bangladesh (IUCN Bangladesh 2015). All of these primates are threatened in Bangladesh, except Stumptail Macaque which is data deficient (op. cit.). Distributions of all these primates are habitat specific except Rhesus Macaque which is found in all forest habitat types as well as in and around human settlements (op. cit.). At present, about $6 \%$ of the land area of the country is covered by forests (Gain 2002) representing three types of forest, such as semi-evergreen and evergreen forest in the northeast and southeast hill tracts, moist deciduous forest in the central region and the Sundarbans mangrove forest in the southwest (Hasan et al. 2013). The Madhupur forest $\left(340 \mathrm{~km}^{2}\right)$ is the largest deciduous forest of Bangladesh (NFA 2007). It is a fragmented and disturbed forest in Bangladesh. It is under high pressure for fuel wood, fallen dry leaves for cooking, grazing, illicit felling and fire hazards (Khan 2010). This forest is enriched with different wild fauna like 115 birds (Khan and Ahsan 2011) and many species of mammals including two nonhuman primates. Logging, fragmentation, urbanization, encroachment, habitat loss, shrinkage of forests, development activities, habitat destruction, jhum cultivation, deforestation, illegal tree falling, over exploitation and potential habitat declining are several factors for mammalian species declination of the country (IUCN Bangladesh 2015). Several works have been done on different aspects of primates in India (Biswas et

\footnotetext{
${ }^{1}$ Corresponding address: likhi.habibon@gmail.com
} 
al. 2009, Kumar and Solanki 2004, 2008 and Solanki et al. 2008) and in Bangladesh (Green 1978, Gittins 1980, Khan and Ahsan 1981, Feeroz et al. 1995 and Feeroz 2001). But data on threats and their conservation in this forest or throughout the country is scanty. The present study aims to describe the existing threats on primates for which their population is being declining and their conservation problems in Madhupur forest. Based on this study it would be possible to formulate effective conservation measures for primate conservation in this forest as well as in this country.

\section{Materials and Methods}

A preliminary field survey was done at first to find out the sites where the primates are found within the Park. Garo tribes, local peoples and forest guards were interviewed informally to know the distribution of Rhesus Macaque and Capped Langur in the park area. The area was visited on foot or by unmotorized vehicle or rickshaw van, animals were observed using $10 \times 42 \mathrm{~mm}$ Bushnell binocular, photograph was taken by using Canon 60D DSLR camera. Fortnightly two days long study was done. A total of 28 days, 280 hours was spent to carry out research at the study area. Surveys were carried out from dawn to dusk to record any disturbances due to human activities such as settlements, grazing, logging, agriculture, hunting and poaching. In association with direct observation a questionnaire survey was done to record information on the histories and present status of the primates', threats, human and primates' conflicts and attitudes of the people towards the primates' conservation of the study area. Both formal and informal questionnaires were used to interview the forest staffs and local people of the peripheral villages. The investigation was done on formally 25 local people (included both male and female) of different occupations like farmer, wood cutter, fire wood collector, cow boy, pineapple garden owner, forest guard, driver, student etc.

Study area: The study was carried out at the Madhupur deciduous forest, Tangail during April 2015 to October 2015. It is situated in the northern part of Bhawal-Madhupur Shal (Shorea robusta) forest tract, somewhat $50 \mathrm{~km}$ south of the Garo Hills of the Meghalaya State of India, and about $110 \mathrm{~km}$ north of Dhaka, the capital of Bangladesh. Geographically, it lies in $24^{\circ} 41.323^{\prime} \mathrm{N}$ and $90^{\circ} .8 .275^{\prime} \mathrm{E}$. The Madhupur forests, commonly known as 'Madhupur Garh', forms a slightly elevated tract of approximately 1-2 $\mathrm{m}$ in height over the surrounding plains. There are numerous depressions with gentle slope intercepting the ridges (Ismail and Mia 1973). Flat ridges run north to south forming the irregular masses of high lands with gentle slopes which are then intercepted by numerous depressions in the form of long and narrow ditches. The forest is partly dense, partly thin and there are scrub jungles also. Two types of tribe (Garos and Koch) are used to live inside the Madhupur forest area and Bengali in the fringe areas. In general, this forest is dominated by Shal trees associated with other tree species like Grewia laevigata, Zizyphus oenoplia, Phyllanthus embelica, Terminalia belerica, etc (Adhikari 2008). 


\section{Results and Discussion Threats}

1. Habitat destruction: As the human population is increasing and the need for material, space, and land use is expanding at an alarming rate, people are rapidly encroaching and destroying the primate habitat for their own need. Non-human primates are just one of the any creatures which are threatened by human sprawl and resource exploitation. The followings are distinctive ways that humans are directly or indirectly responsible for the loss of habitat essential for primates' endurance in the study area:

Expansion of agricultural land and crop production: It was observed that local people at the forest edges were expanding their cultivated land regularly. By destroying forest habitat they preferred to cultivate paddy (Oryza spp.), banana (Musa spp.), pineapple (Ananas sativus), zinger (Zingiber officinale), turmeric (Curcuma longa), lemon (Citrus aurantifolia), seasonal vegetables etc. (Plate 1). Even after clearing the forest area the rubber garden was established. Even, inside the deep forest some landmass were cleared up and these crops were planted. Thus forest became fragmented and it was very tiresome for primates' movement especially for langurs' because they do not prefer to use the forest floor during movement from one place to another.

Logging and firewood collection: It has already mentioned that the forest areas were cleared up regularly and rapidly. Due to increase of human populations and rapid urbanization, the existing forest areas are still facing continuous threats of degradation. In addition to this, human population pressure has accelerated the fragmentation of wildlife habitats. Illegal logging (Plate 2) caused the destruction of both large and undergrowth canopies. The fire wood collectors caused massive habitat destruction throughout the year for their livelihood. They took not only the dried plants but also they broke or cut down live branches (young and thin branches) of the plants, kept down on the forest floor and collected after drying. The wood collectors regularly entered into the forest for wood collection either it was live or dry. It was known from the wood collector that the undergrowth collection was about 80 pounds in a day and sold in local market in 400-500 BDT. It was reported from the collectors that in total, 25 to 30 collectors regularly used to collect the woods from the area of Rasulpur, Beribaid, Lohoria and Dokhola of the National Park. Several groups (consisting of 3 to 8 people in each group) are responsible for illegal logging in this forest. Recently forest department has taken initiative to stop illegal logging and habitat destruction by implementing community participation management programme. Local people informed that due to this initiative, illegal logging and habitat destruction are becoming less in recent past years than the previous years. Moreover, the Rubber Garden area was seen quite well protected by local government branch office of related ministry and guards strictly patrolling the garden area. As a result of cutting down the large fruit plants for various purposes both primates were facing serious problems and invaded the local peoples' garden or entered into the human habitation for food. It was found that the Hindura (Mellotus philippensis) and Ziga (Lannea coromandelica) were highly cut down by both illegal logger and fire wood collectors. 
Mammalian habitats have been destroyed and fragmented in an alarming rate because of accelerating human population pressure and different anthropogenic factors (IUCN Bangladesh 2015). Illegal timber collectors collect both large sized hard wood plants which eventually affect upper canopy used by arboreal mammals like langurs and other primates, and soft wood plants which provide food for them, creates uneven gaps in the forest and eventually affects both feeding and foraging of arboreal mammals (op. cit.). Habitat destruction was recorded as the principal threats of Capped langur in Northeast India (Biswas et al. 2009, Srivastava 2006 and Kumar and Solanki 2004). Illegal wood and fire wood collectors are also responsible for habitat destruction in Lantang National Park of Nepal (Regmi and Kandel 2008). Habitat loss and degradation are the causes of population declination of Capped Langur (Kumar and Solanki 2004). Due to the collection of non-timber forest the depletion of food plants important to the langurs were found to be most serious threats in Arunachal Pradesh in India (Kumar and Solanki 2008). Biswas et al. (2009) recorded rapid habitat loss, fragmentation, alteration of habitat, jhoom cultivation, hydro electrical dam construction etc. were severe problems of macaques conservation in the protected areas of Assam. The extraction of plant species including food plants by the local people inhabiting the surrounding area of the sanctuary is another threat of Capped Langur and other primate species depletion (Kumar and Solanki 2003, Kumar 2006). Kumar and Solanki (2008) mentioned the clear felling of mature forests for agriculture and settlements in the area which were bordering the Nameri National Park in Assam and Pakke Wildlife Sanctuary in Arunachal Pradesh in India. In Madhupur forest, it was found that the Capped langur is confined to a fragmented area. Kumar and Solanki (2008) also reported that the Capped langur is confined to a fragmented area in Arunachal Pradesh of India.

2. Hunting: It was reported that, local people used several methods to hunt Rhesus Macaque and Capped Langur. From the questionnaire survey it was noted that, ethnic people use their pet dog and fruits bait trap for hunting primates. Fruits bait traps usually used seasonal fruits (banana, pineapples, jackfruits and litchi) when these were available. Rhesus Macaque often trapped for pet or for using as performance monkey. During the study period one infant was trapped in the Harinatala village and later used as pet animal and the local people informed that three adult macaques were kept for pet.

In this forest, Capped langurs are under high hunting pressure due to their small group composition. Hunting was less reported in forest edges and other human dominated areas where forest guards or local people or visitor were regularly seen to visit. Moreover, the hunter preferred adult to hunt comparatively which supplied more flesh than younger one.

From the questionnaire survey it was revealed that the Capped langur was hunted for food during special occasion (Christmas day) of the ethnic people or opportunistically. It was also noted that ethnic people of 15-25 ages, mostly illiterate were known to be active hunter. Ethnic people were found to be engaged in group hunting (Plate 3).

Hunting and poaching are the major threats of mammals (IUCN Bangladesh 2015). Santals and Garo community of northern part of the country go out for group hunting in winter (op. cit.). Rhesus Macaques have been wiped out from the Sal forest of the north Bengal due to over hunting (op. cit.). Ethnic people hunt the primates for food which was 
a cause of threat in Assam (Biswas et al. 2009) and Arunachal Pradesh in India (Kumar and Solanki 2008), Northeast India (Srivastava 2006 and Kumar and Solanki 2004). Hunting for medicinal purposes and artifacts for socio-cultural practices and religious and cult ceremonies are the causes of population declination (Kumar and Solanki 2004, 2008 and Biswas 2009). Hunting, poaching and habitat destruction are frequent in the adjacent forest areas of Pakke Wildlife Sancturay (Kumar and Solanki 2004).

3. Diseases: Local people reported that diarrhoea was known to occur at the child age of Rhesus Macaque and two were known to die. Another disease was found during study period at Beribaid beat area where the tail of Macaque at first was infected, wounded and finally fell off (Plates 4a,b) and gradually legs and other body parts were affected, fell off and eventually the animal died. During this time the infected macaque suffered from nausea and gradually became weak and thin. It was reported from the forest guards that two juveniles died due to this disease. In the study period one was died and two juveniles were seen to be infected.

4. Accident: The construction of roads inside the forest creates a severe disturbance which forced primates to invade the gardens of different fruits and agricultural fields near human habitation. Moreover, Mymensingh-Tangail highway with numerous bends in different areas has crossed and fragmented the potential habitat of the primates in forest area. During the study period, 4 accidents were reported; causing 4 spot dead and 2 injured (Table 1). All these accidents happened during crossing the road except Monarbaid beat while one adult male was jumped from one tree to other over the road and fell down on the running bus and injured severely. Many mammalian species die on roads through the crash with vehicles as many forest areas in the country have been bisected by roads, highways and railway roads (IUCN Bangladesh 2015). Road accident is recorded as a threat in Langtang National Park of Nepal (Regmi and Kandel 2008, Kumar and Solanki 2008 and Minhas et al. 2010).

Table 1. Consequence of road accident occurred in Madhupur National Park.

\begin{tabular}{lcccccc}
\hline Location & \multicolumn{3}{c}{ Rhesus Macaque } & \multicolumn{3}{c}{ Capped Langur } \\
\cline { 2 - 7 } & $\begin{array}{l}\text { Adult } \\
\text { Male }\end{array}$ & Juvenile & Consequence & $\begin{array}{c}\text { Adult } \\
\text { female }\end{array}$ & Infant & Consequence \\
\hline $\begin{array}{l}\text { Road near the Jaloi } \\
\text { cottage }\end{array}$ & 1 & - & Dead & 1 & 1 & Dead \\
$\begin{array}{l}\text { At the middle of the } \\
\text { road passing through the } \\
\text { Jaloi and Rosulpur beat }\end{array}$ & 1 & - & Dead & - & - & - \\
$\begin{array}{l}\text { Monarbaid beat } \\
\begin{array}{l}\text { At the middle of the } \\
\text { road passing through the }\end{array}\end{array}$ & 1 & - & Injured & - & - & - \\
Jaloi and rosulpur beat & & 1 & Injured & - & - & - \\
\hline
\end{tabular}


5. Tourist activities and others: Uncontrolled tourist activities were recorded in Madhupur Forest especially in winter and during any religious festival such as, Eid festival, Puja etc. Several areas (Shontoshpur, Dokhola, Beribaid beat) are being used as picnic spots or for tourist activities (Plate 5). Visitors were seen screaming, shouting and laughing high in forest trails. People were seen carrying out loud speakers and cooking food at the forest edges. At Beribaid Beat, Capped Langur was seen quite irregular near the picnic spot or any other event spot. Uncontrolled tourist activities severely interrupt normal daily activity of diurnal mammals (IUCN Bangladesh 2015). Loud sound, curious activities and non-ecofriendly activities by the visitors in the protected areas force the mammalian species to leave their home ranges (op. cit.). But large numbers of Rhesus Macaques were recorded in Shontoshpur, Dokhola and Beribaid beat where tourists and visitors came regularly and provided foods to them. Rhesus Macaques are being habituated with provisioning for tourist attraction (IUCN Bangladesh 2015). Tourists visiting these areas get a chance to feed these monkeys (op. cit.). The pesticides and insecticides used in the agricultural fields were known to get mixed with local ponds, drain water, causing serious problems to primates which usually drink this water.

Conflicts between human and non-human Primates

During the study period, following two types of conflicts were observed.

Conflicts between human and Rhesus Macaque: The Rhesus Macaque which raided the crops just before harvesting severely damaged crops like paddy and pineapples. When the pineapple fruits became matured, Rhesus Macaques entered into the forest-fringed gardens and caused massive damage, as each individual got a hold of at least one fruit during each raid. The macaques also raided ripe jackfruit (Artocarpus heterophyllus) (Plate 6).

Conflicts between human and Capped Langur: While different foods were available near human habitation, the Capped Langur started to move to human habitation area from forest area. They raided home gardens, fruits and vegetables garden destroying paddy (Oryza spp.), Papaya (Carica papaya), Banana (Musa spp.), Black berry (Syzygium spp.), Dewa (Artocarpus lacucha), Mango (Mangifera indica), Lichee (Litchi chinensis), Sajna (Moringa oleifera), Nut (Cocos nucifera), Jackfruit (Artocarpus heterophyllus), Guava (Psidium guajava), bamboo (Bambusa spp.). Capped Langur was also recorded to destroy vegetables, fresh leaves, plant shoots, buds, flowers, and fruits. The farmers informed that about $15-25 \%$ crops were destroyed during a season. Crop raiding by primates was also reported by several authors in different countries (Priston 2005 and Siex and Struhsaker 1999). It was reported that both Capped Langur and Rhesus Macaque spoiled more crops than they actually eat; local people informed that the Rhesus Macaque was the most frequent crop raiders than Langur. Similar observations were also reported by Chalise (2000).

Crop preference: From the questionnaire survey it was found that the primates severely caused paddy field destruction (Fig. 1). Besides the direct loss, they caused loss of crops by feeding upon the flowering and fruiting trees which reduce fruit production considerably. Rhesus Macaque highly raided the paddy fields. Cereals, fruits and tubers 
are the most preferred and became vulnerable for raiding by macaques (Chalise 2000). Khatry (2006) reported that maize is the prominently vulnerable crops for raiding by primates.

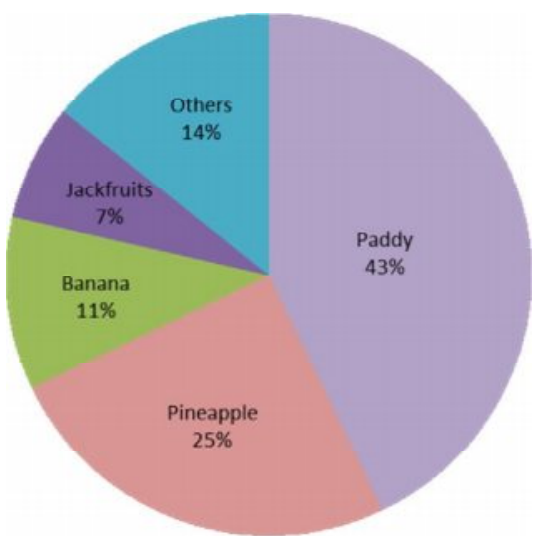

Fig.1. Crop damaged by primates.

Crop protection strategies: To protect crop fields from primates, farmers used many methods. The methods included patrolling and guarding the fields by farmers including their children and chasing of primates by using bamboo stick, catapult and branch of tree. Local people informed that people had to guard the paddy field with bamboo sticks, catapult and other tools to protect crops. Pineapple field owners had to keep permanent guard (Plate 7) to protect crops till harvesting. Regmi and Kandel (2008) reported that guarding of crop fields, scarecrows, tin-box, stones and catapults, keeping dogs, fencing with thorny twigs etc. are the methods used to protect the crops in Langtang National Park of Nepal.

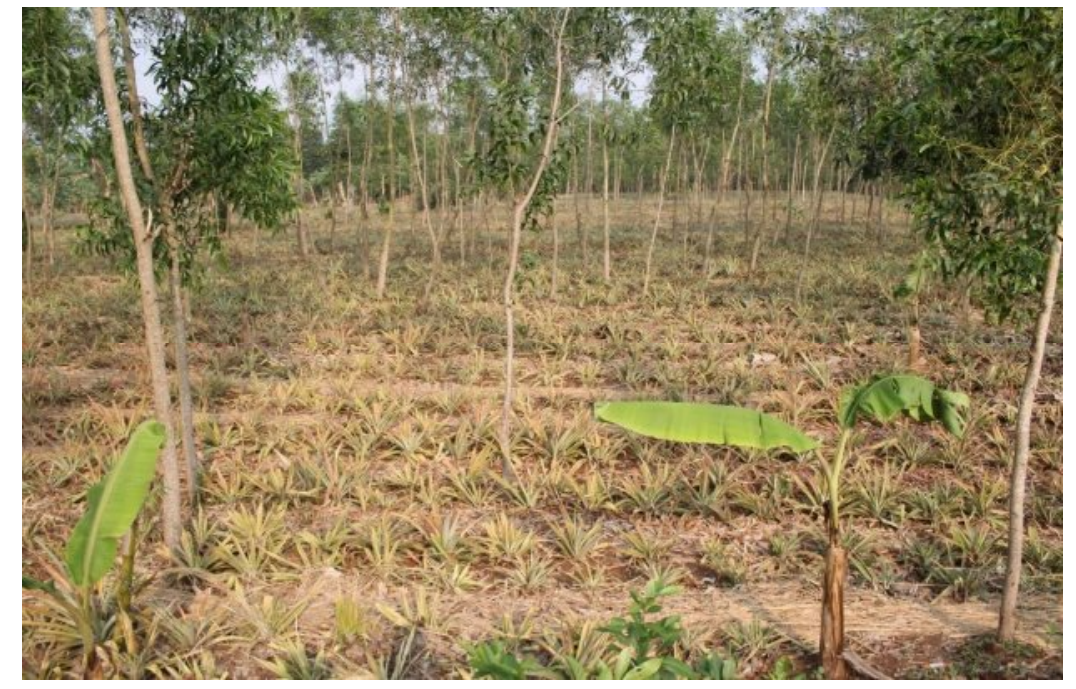

Plate 1. Cultivation of pineapple by clearing the primate habitat. 


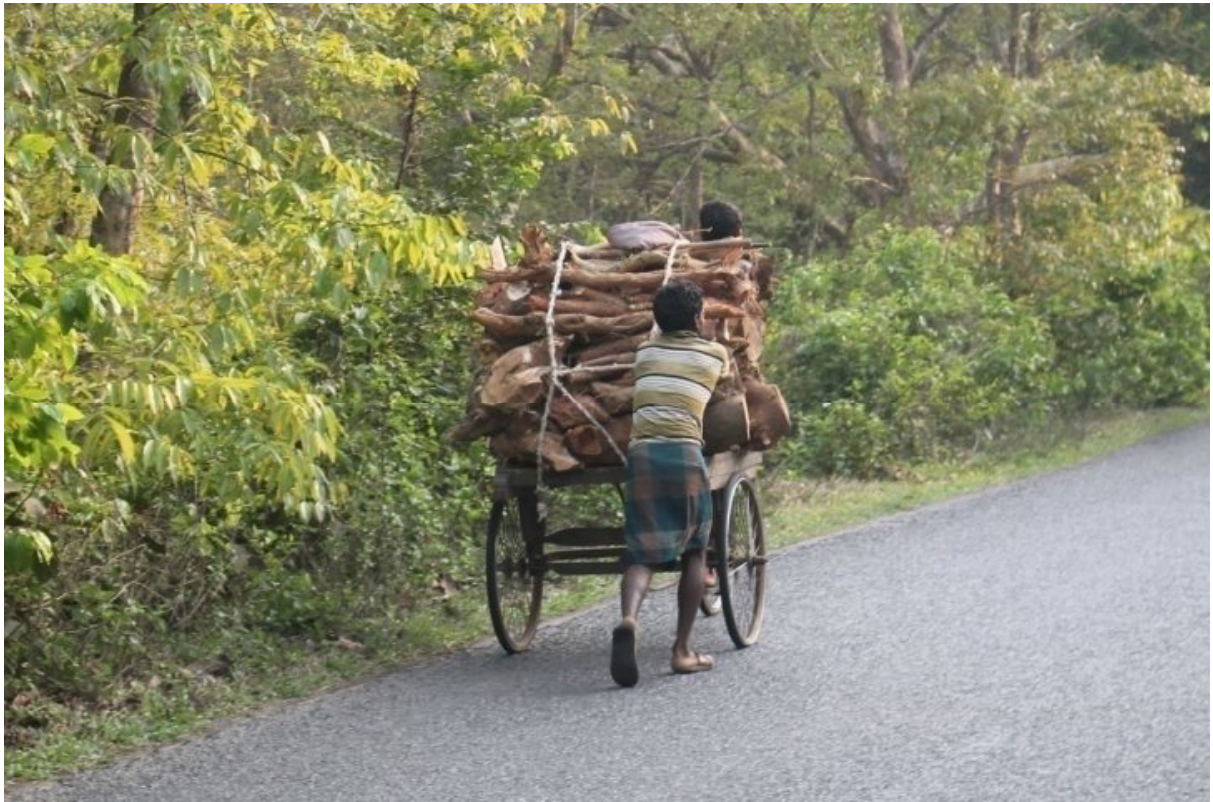

Plate 2. Regular practice of wood logging activities in MadhupurNational Park.

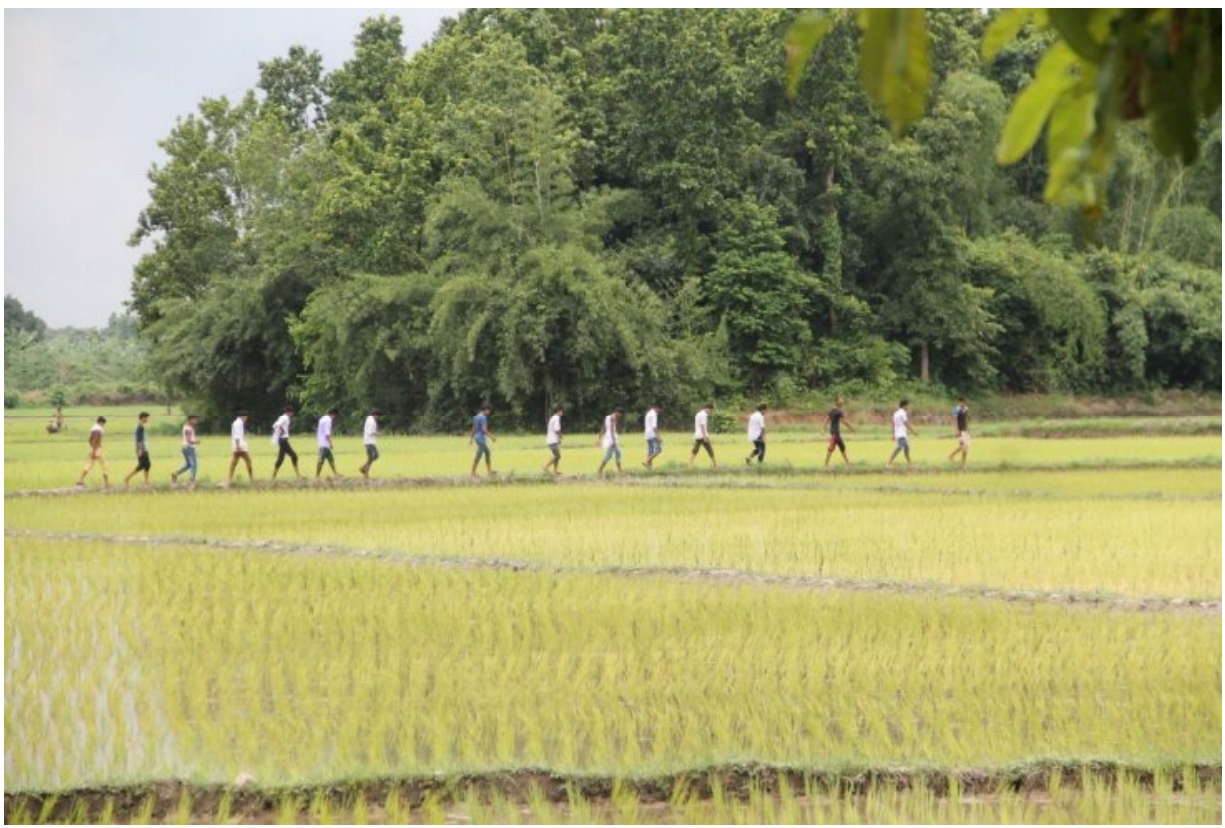

Plate 3. Ethnic group go out for group hunting in Madhupur National Park. 


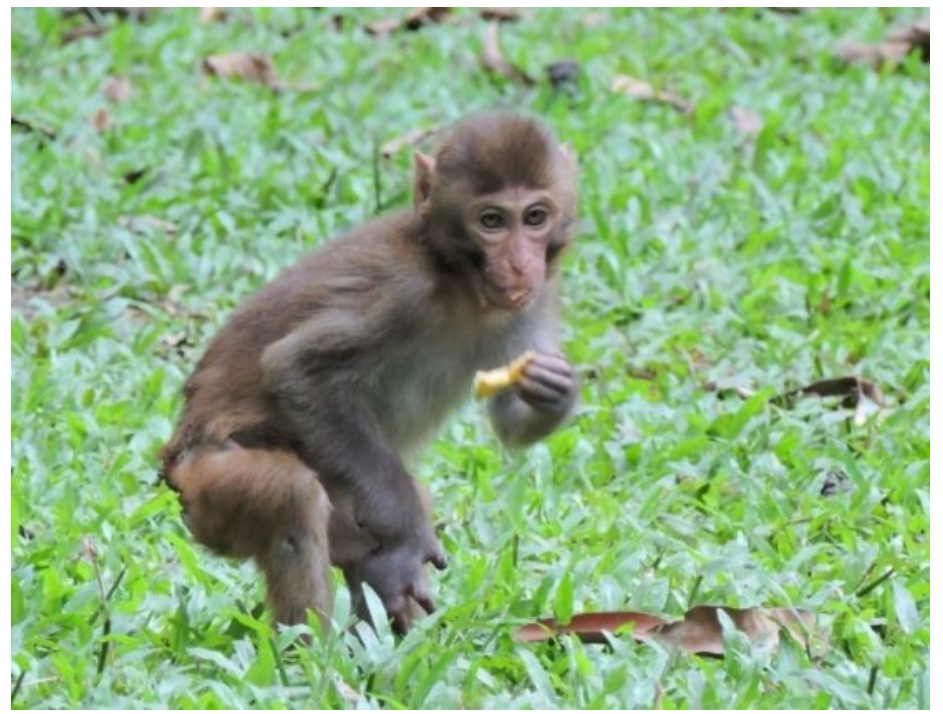

(a)

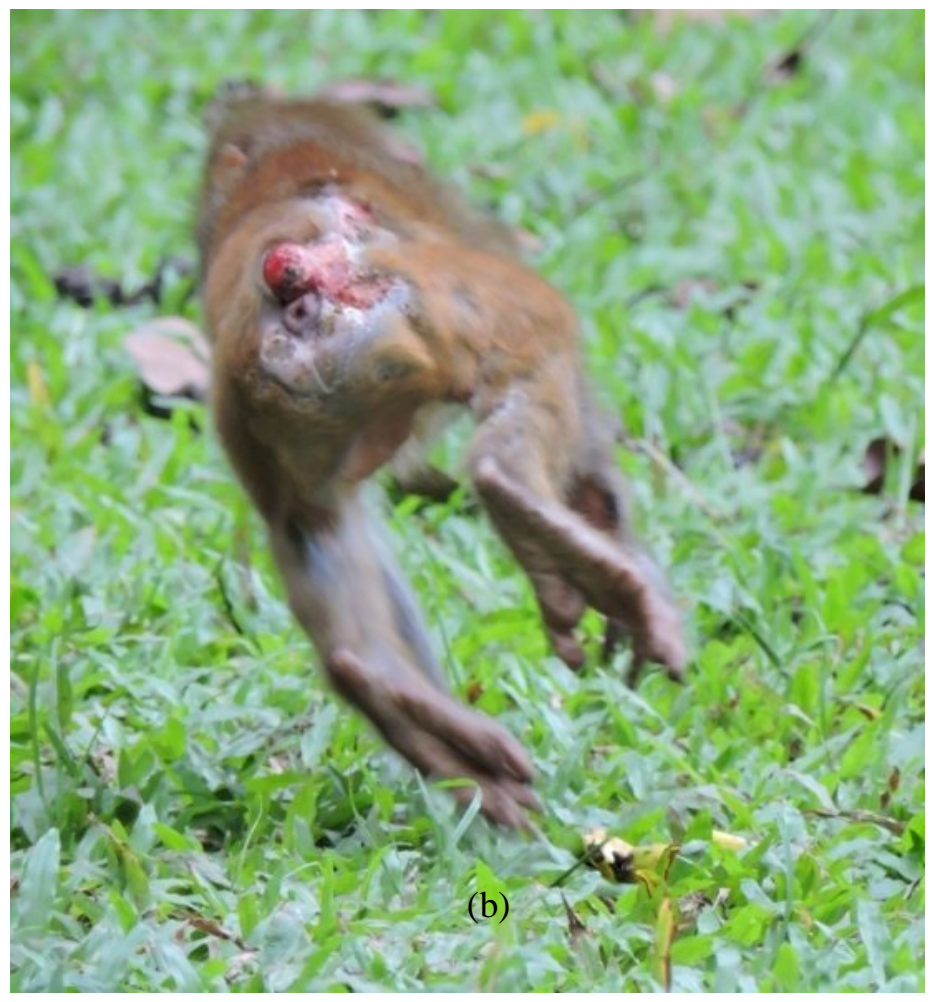

Plate 4. A young Rhesus Macaque having right ill hand (a) and dropped tail (b). 


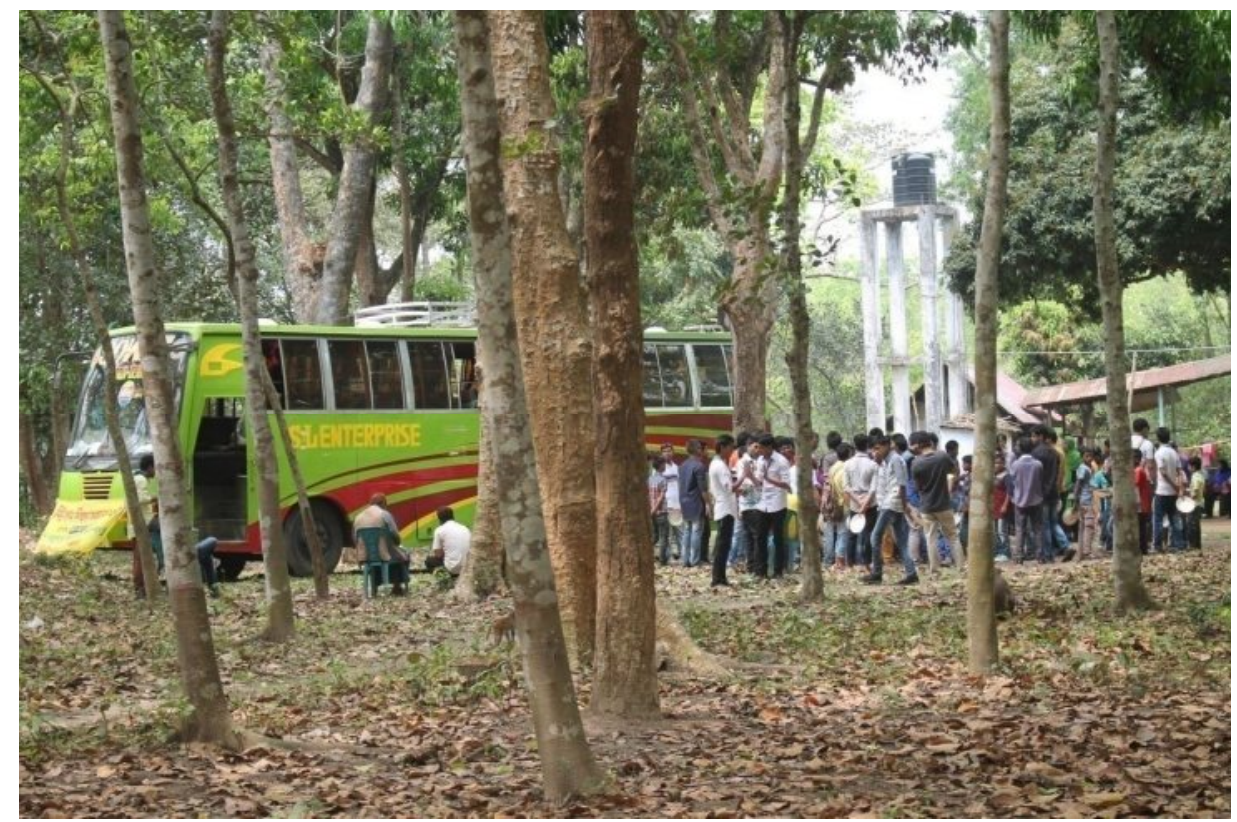

Plate 5. Tourist activities in Madhupur National Park.

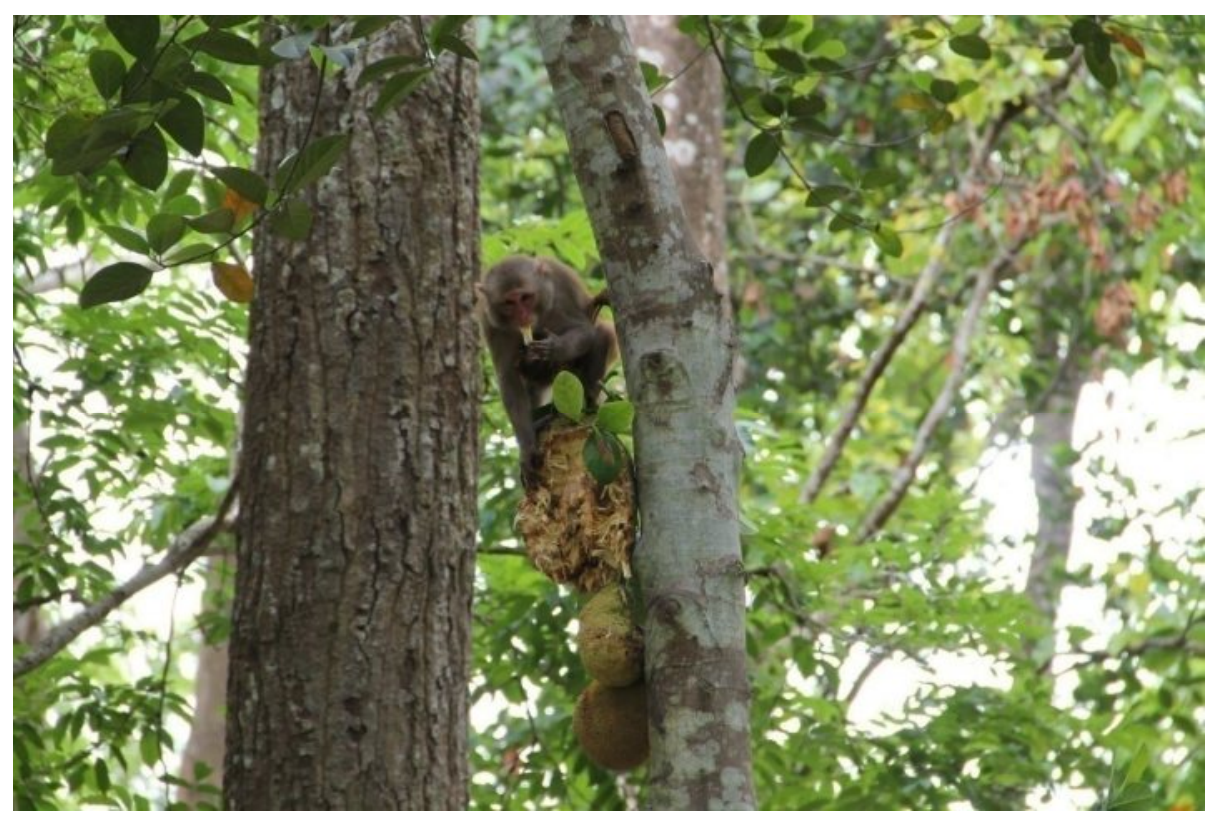

Plate 6. Rhesus Macaque raided the ripe jackfruit. 
The present study has given an idea about the existing threats of primates' conservation in Madhupur forest of Bangladesh. More research should be conducted to formulate a management plan and to aware people to conserve the primates' population, especially the Capped Langur in this forest.

\section{Acknowledgements}

The authors would like to express especial gratitude to Ministry of Science and Technology (R\&D project), Government of the People's Republic of Bangladesh, for providing financial support for this study. The authors are also thankful to the Ministry of Environment and Forest, Bangladesh for giving permission to conduct this study in Madhupur National Park.

\section{References}

Adhikari, R. 2008. Madhupur Garer Biboron. Unpublished Report. pp. 1-5.

Biswas, J., N. Das, D.K. Borah, A. Sangma, P.C. Ray and J. Das. 2009. Status and distribution of least known primate species: Slow Loris and Capped langur in the Protected Areas of Assam, India and its Feeding Ecology, Final Report of Primate Research Centre NE India, Wildlife Information Liaison Development, Zoo Outreach Organization and Margot Marsh Biodiversity Foundation Collaborative Project. (No. PRCNE/Tecr-7), J. Biswas (editor). 1-39 pp.

Chalise, M.K. 2000. Behavior study of Assamese monkeys (Macaca assamensis) of Makalu-Barun Area, Nepal. In: the Proceedings of IIIrd National Conference on Science and Technology. 2: 1323-1332.

Chopra G. Bhoombak and P. Kumar. 2013. Prevalence of non-human primates in Morni Hills of Haryana, India: A survey. Tigerpaper. 40 (2): 1-9.

Feeroz, M.M. 2001. Species diversity and population density of non-human primates in north-east and south-east of Bangladesh. Ecoprint. 8(1): 53-57.

Feeroz, M.M., M.A. Islam and M.M. Kabir. 1995. Status, distribution and conservation of nonhuman primates of Bangladesh. Kyoto Univ. Overseas Research Report of Studies on Asian Non-human Primates. 9: 73-82.

Gain, P. 2002. Bangladesh Environment: Facing the 21st Century. Society of Environment and Human Development (SEHD), Dhaka, Bangladesh.

Gittins, S.P. 1980. A Survey of the Primates of Bangladesh. Project Report to the Forest Department of Bangladesh.

Green, K.M. 1978. Primates of Bangladesh: a preliminary survey of population and habitat. Bio. Con.13: 11-160.

Hasan, K., M.A. Aziz, S.M.R. Alam, Y. Kawamoto, Lisa Jones- Engel, R.C. Kyes, S. Akhtar, S. Begum and M.M. Feeroz. 2013. Distribution of Rhesus Macaques (Macaca mulatta) in Bangladesh: Interpopulation Variation in Group Size and Composition. Prim. Con. 26(1):125-132.

Ismail, M. and M.M. Mia. 1973. Studies on some deciduous sal forests of Bangladesh; Ecology of Bangladesh Vegetation. Botanical Survey of Bangladesh, University of Dhaka, Dhaka.

IUCN Bangladesh. 2015. Red List of BangladeshVolume 2: Mammals. IUCN International Union for Conservation of nature, Bangladesh Country Office, Dhaka, Bangladesh. xvi+232 pp.

Khan, S.I. 2010. Frugivorous birds and seed dispersal in Madhupur National Park and Chittagong University Campus, Bangladesh. Unpublished M.Phil. Thesis. Department of Zoology, University of Chittagong. xi+209. pp.

Khan, S.I. and M.F. Ahsan. 2011. Birds of the Madhupur National Park, Bangladesh. Bangladesh J. Zool. 39(1): 49-53. 
Khan, M.A.R. and F. Ahsan. 1981. The group structure, composition and age-sex relationship of primates in Bangladesh. Proceedings of the 3rd National Zoological Conference, Bangladesh. pp. 287-302.

Khatry, P. 2006. Study on Monkey-Human conflict in Vijayapur area, Dharan, Eastern Nepal. M. Sc. Thesis, Tribhuvan University, Kathmandu, Nepal.

Kumar, A. 2006. Studies on Ecological and behavioural aspects of capped langur, Trachypithecus pileatus (Blyth 1843) in Pakhui Wildlife Sanctuary, Arunachal Pradesh, India. Ph. D. thesis, North-eastern Hill University, Meghalaya, India.

Kumar, A. and G.S. Solanki. 2003. Food preference of Rhesus monkey Macaca mulatta during the pre-monsoon and monsoon season, Pakhui Wildlife Sanctuary, Arunachal Pradesh, India. Zoos's Print J. 18(8):1172-1174.

Kumar, A. and G.S. Solanki. 2004. Ethno-sociological impact on capped langur (Trachypithecus pileatus) and suggestions for conservation: a case study of Reserve Forest in Assam, India. J. Nat. Con. 16(1): 107-113.

Kumar, A. and G.S. Solanki.2008. Population status and conservation of capped langurs (Trachypithecuspileatus) in and around Pakke Wildlife Sanctuary, Arunachal Pradesh, India. Prim. Con. 16(1): 107-113.

Minhas, R.A., K.B. Ahmed, M.S. Awan and N.L. Dar. 2010. Habitat utilization and feeding biology of Himalayan Grey Langur (Semnopithecus entellus ajex) in Machiara National Park, Azad Kashmir, Pakistan. Zool. Res. 31: 1-13.

*NFA 2007. National Forest and Tree Resources Assessment 2005-2007, Bangladesh.Ministry of Environment and Forest (MoEF), Bangladesh.

*Priston, N.E.C. 2005. Crop-Raiding by Macaca ochreata brunnescens in Sulawesi: Reality, Perceptions and Outcomes for Conservation. PhD thesis, University of Cambridge, Cambridge, UK.

*Regmi, G.R. and K. Kandel. 2008. Population Status, Threats and Conservation Measures of Assamese macaque (Macaca assamensis) in Langtang National Park, Nepal. A final report submitted to Primate Society of Great Britain, UK.

Siex, K.S. and T.T. Struhsaker. 1999. Colobus Monkeys and Coconuts: A Study of Perceived Human-Wildlife Conflicts. J. Appl. Ecol. 36:1009-1020.

Solanki, G.S., A. Kumar and B.K. Sharma. 2008. Feeding ecology of Trachypithecus pileatus in India. Int. J. Pri. 29:173-182.

Srivastava, A. 2006. Ecology and conservation of the golden langur, Trachypithecus geei, in Assam, India. Prim. Con. 21: 163-170. 